\title{
FAKTOR RISIKO KEJADIAN STUNTING PADA ANAK USIA 12-36 BULAN DI KECAMATAN PATI, KABUPATEN PATI
}

\author{
Hana Sofia Anugraheni, Martha Irene Kartasurya ${ }^{*}$ \\ Program Studi Ilmu Gizi Fakultas Kedokteran Universitas Diponegoro \\ Jl.Dr.Sutomo No.14, Semarang, Telp (024) 8453708, Email : gizifk@undip.ac.id
}

\begin{abstract}
Background: In 2007, the prevalence of stunting among underfive children in Pati was 42,2\%. Stunting may result in low productivity, increase risk of degenerative disease and increase risk of low birth weight in the future. The aim of this study was to investigate risk factors for stunting among 12 - 36 month old children at Pati Subdistrict in Pati District.

Methods: This study was conducted in a case control design on 29 cases (stunting) and 29 controls (normal). Stunting was determined by HAZ <-2SD of WHO child growth standart. Information on birth length and weight, gestational age, exclusive breastfeeding period, first complementary feeding time and complementary feeding score at $6-12$ month old were obtain through interviews using structured questionnaires. Analysis was conducted by Pearson Chi-Square test to find out stunting risk factors.

Results: In stunting group: $55.2 \%$ of the fathers worked as factory workers, laborers and farmers and $6.9 \%$ were jobless. The mothers who graduated from high degree education were $17.2 \%$ in control group, whereas only $6.9 \%$ in cases group. This study showed that risk factors for stunting on 12-36 month old children were prematurity $(p=0.025 ;$ OR $=10.67)$ and low birth length $(p=0.000 ;$ OR=2.81). Birth weight $(p=0.112)$, exclusive breastfeeding period ( $p=0.195)$, first complementary feeding time $(p=0.113)$ and complementary feeding score $(p=1.000)$ were not risk factors of stunting, in this study.

Conclusion: Risk factors for stunting among 12 - 36 month old children at Pati Subdistrict were prematurity and low birth length.
\end{abstract}

Keywords: stunting, risk factors; children $12-36$ months; prematurity; length birth

\section{ABSTRAK}

Latar Belakang: Tahun 2007, prevalensi stunting pada balita di kabupaten Pati adalah 42,2\%. Stunting dapat berakibat pada penurunan produktivitas, peningkatan risiko penyakit degenaratif dan peningkatan kelahiran bayi dengan berat badan lahir rendah di masa mendatang. Penelitian ini bertujuan untuk mengetahui faktor-faktor risiko kejadian stunting pada balita usia 12-36 bulan di Kecamatan Pati, Kabupaten Pati.

Metode: Penelitian ini dilakukan dengan rancangan kasus kontrol pada 29 kasus (stunting) dan 29 kontrol (normal). Kriteria stunting ditentukan berdasarkan skor z indeks $T B / U<-2 S D$ menurut WHO child growth standart. Data panjang badan lahir, berat badan lahir, usia kehamilan, lama ASI eksklusif, usia pengenalan MPASI dan skor pemberian MP-ASI usia 6-12 bulan diperoleh melalui wawancara menggunakan kuesioner terstuktur. Analisis dilakukan dengan Pearson Chi-Square untuk mengetahui faktor risiko kejadian stunting.

Hasil: Pada kelompok stunting: 55,2\% ayah bekerja sebagai sebagai buruh pabrik, kuli dan petani serta 6,9\% tidak bekerja. Ibu dengan pendidikan tamat akademi/perguruan tinggi adalah sebanyak 17,24\% pada kelompok normal dan 6,9\% pada kelompok stunting. Penelitian ini menunjukkan, faktor risiko kejadian stunting pada balita 12 -36 bulan adalah prematuritas $(p=0,025 ; O R=10,67)$ dan panjang badan lahir rendah $(p=0,000 ; O R=2,81)$. Berat badan lahir $(p=0,112)$, lama pemberian ASI eksklusif $(p=0,195)$, usia makan pertama $(p=0,113)$ dan skor MP-ASI $(p=1,000)$ bukan merupakan faktor risiko kejadian stunting pada penelitian ini.

Simpulan: Faktor risiko kejadian stunting pada anak usia 12-36 bulan di kecamatan Pati, kabupaten Pati adalah prematuritas dan panjang badan lahir rendah (pendek).

Kata Kunci: stunting; faktor risiko; anak usia 12-36 bulan; prematuritas; panjang badan lahir

\section{PENDAHULUAN}

Prevalensi balita stunting secara nasional menurun sebanyak $1,2 \%$ yaitu $36,8 \%$ pada tahun 2007 menjadi 35,6\% pada tahun 2010. Meskipun demikian, angka prevalensi tersebut masih lebih tinggi dibandingkan angka prevalensi gizi kurang dan buruk (17,9\%), kekurusan $(13,3 \%)$ serta kegemukan (14\%). ${ }^{1}$ Identifikasi balita stunting berdasakan indikator $\mathrm{TB} / \mathrm{U}$ menurut $W H O$ child growth standart adalah jika nilai $z$-score $\mathrm{TB} / \mathrm{U}<-2$ SD. ${ }^{2}$ Kejadian stunting sering dijumpai pada anak usia 12 - 36 bulan dengan prevalensi sebesar 38,3 -

${ }^{*}$ Penulis Penanggungjawab 
41,5\%. ${ }^{1}$ Jika kondisi ini terjadi pada masa golden period perkembangan otak (0-3 tahun) maka otak tidak dapat berkembang dengan baik. ${ }^{3}$ Hal tersebut berakibat pada penurunan kemampuan intelektual dan produktivitas, peningkatan risiko penyakit degeneratif dan kelahiran bayi dengan berat badan lahir rendah atau prematur di masa mendatang. ${ }^{3,4}$

Ibu dengan gizi kurang sejak trimester awal akan melahirkan bayi dengan berat lahir rendah (BBLR) yang kemudian akan tumbuh menjadi balita stunting. ${ }^{5}$ Sebuah penelitian di Indramayu menunjukkan bahwa karakteristik bayi saat lahir mempengaruhi pola pertumbuhan post natal bayi. ${ }^{6}$ Bayi yang berukuran kecil untuk usia kehamilannya mengalami kegagalan tumbuh sejak dalam kandungan. ${ }^{7}$ Bayi prematur dengan berat lahir rendah, berat dan panjang badannya selain dipengaruhi oleh status gizi ibu, juga dipengaruhi oleh usia kehamilan. ${ }^{5}$ Bayi tersebut memiliki ukuran panjang, berat dan lingkar kepala yang kurang dari ukuran normal. Penelitian di Brazil dengan desian kohort melaporkan bahwa kelompok bayi lahir prematur memiliki risiko stunting saat usia 12 bulan sebesar 2,35 kali dan saat usia 24 bulan sebesar 2,30 kali. $^{8}$

Bayi yang lahir normal juga dapat berisiko stunting jika asupan gizinya kurang. ${ }^{5}$ Kualitas dan kuantitas MP-ASI yang baik merupakan komponen penting dalam makanan balita karena mengandung sumber zat gizi makro dan mikro yang berperan dalam pertumbuhan linier. ${ }^{3}$ Penelitian di Padang melaporkan bahwa pola asuh makan berpengaruh terhadap status gizi balita. ${ }^{9}$ Pemberian pola asuh makan yang memadai berhubungan dengan baiknya kualitas konsumsi makanan balita, yang pada akhirnya mempengaruhi status gizi balita tersebut. ${ }^{10}$ Berdasarkan penelitian yang dilakukan di Banten, pemberian ASI/MP-ASI yang kurang dan pemberian MP-ASI/susu formula terlalu dini dapat meningkatkan risiko stunting karena bayi cenderung lebih mudah terkena penyakit infeksi seperti diare. ${ }^{11}$ Pemberian MP-ASI pada usia dini juga dapat meningkatkan risiko stunting pada balita. ${ }^{12}$

Hasil Riset Kesehatan Dasar tahun 2010 menunjukkan bahwa Provinsi Jawa Tengah memiliki prevalensi stunting sebesar 33,9\%. ${ }^{1}$ Beberapa kabupaten/kota diketahui masih memiliki angka prevalensi stunting yang tinggi, salah satunya adalah kabupaten Pati. Menurut hasil Riset Kesehatan Dasar Provinsi Jawa Tengah pada tahun 2007, prevalensi stunting di kabupaten Pati mencapai $42,2 \% .^{13}$
Penelitian ini bertujuan untuk mengetahui faktor-faktor risiko kejadian stunting (pendek) pada balita usia 12-36 bulan di Kecamatan Pati, Kabupaten Pati. Tujuan penelitian disusun untuk menguji hipotesis yaitu panjang badan lahir, berat badan lahir, usia kehamilan, lama ASI eksklusif, usia pengenalan MP-ASI dan pemberian MP-ASI usia 6-12 bulan merupakan faktor risiko kejadian stunting pada balita usia 12-36 bulan di kecamatan Pati, kabupaten Pati.

\section{METODE PENELITIAN}

Penelitian ini merupakan penelitian observasional dalam bidang gizi masyarakat dengan rancangan studi kasus kontrol yang menggunakan pendekatan retrospektif. Penelitian dilaksanakan di wilayah kerja puskesmas Pati I, kabupaten Pati pada bulan Mei - Juni 2012.

Populasi target penelitian adalah balita usia 12-36 bulan di kecamatan Pati, kabupaten Pati pada tahun 2012, sedangkan populasi terjangkau adalah balita usia 12-36 bulan yang tercatat di posyandu desa Mustokoharjo, Dengkek, Panjunan, Sidoharjo, Winong, Pati Lor dan Geritan. Besar sampel minimal yang diperlukan dihitung berdasarkan rumus besar sampel pada studi kasus kontrol berpasangan dengan tingkat kemaknaan $95 \% \quad(Z \alpha=1,96), \quad$ kekuatan $90 \% \quad(Z \beta=1,282)$, $\mathrm{OR}=3,8$ sehingga diperoleh sampel minimal sebanyak 27 orang dengan perbandingan sampel antara kasus dan kontrol adalah 1:1. Pemilihan sampel penelitian dilakukan dengan menggunakan teknik consecutive sampling berdasarkan kriteria inklusi yaitu anak usia 12-36 bulan, anak bersedia menjadi responden, nilai z-score untuk indeks TB/U <-2 SD (kelompok kasus) dan z-score untuk indeks TB/U -2 SD s/d +2SD (kelompok kontrol). Pemilihan kontrol dilakukan dengan matching terhadap kelompok umur dan jenis kelamin. Kontrol dipilih berdasarkan asal desa yang sama atau berdekatan dengan kelompok kasus. Selanjutnya, pemilihan kontrol disamakan dengan umur ( \pm 3 bulan) dan jenis kelamin masing-masing individu pada kelompok kasus.

Variabel bebas dalam penelitian ini adalah panjang badan lahir yang dikategorikan normal $(\geq 48 \mathrm{~cm})$ dan pendek $(<48 \mathrm{~cm})^{14}$, berat badan lahir yang dikategorikan normal $(\geq 2500)$ dan rendah $(<2500 \mathrm{~g})^{14}$, usia kehamilan yang dikategorikan cukup bulan $(\geq 37$ minggu) dan prematur $(<37$ minggu $)^{14}$, lama ASI eksklusif yang dikategorikan ASI eksklusif dan non-ASI eksklusif ${ }^{15}$, usia pengenalan MP-ASI yang dikategorikan $<6$ bulan dan $\geq 6$ bulan $^{16}$ dan pemberian MP-ASI usia 6-12 
bulan berdasarkan total skor pertanyaan yang diubah ke dalam skor $\mathrm{T}$ yang kemudian dikategorikan baik jika skor $\mathrm{T} \geq$ mean dan kurang jika skor $\mathrm{T}<\mathrm{mean}^{17}$. Variebel bebas tersebut diperoleh melalui wawancara langsung dengan ibu sampel menggunakan formulir penelitian. Variabel terikat dalam penelitian ini adalah status gizi stunting pada anak usia 12-36 bulan. Status gizi stunting diperoleh melalui pengukuran tinggi badan menggunakan microtoise dengan kapasitas $200 \mathrm{~cm}$ dan tingkat ketelitian $0,1 \mathrm{~cm}$, selanjutnya dilakukan perhitungan $z$-score tinggi badan menurut umur $(\mathrm{TB} / \mathrm{U})$ menggunakan software WHO antro 2005.

Data yang dikumpulkan pertama kali adalah data tinggi badan balita usia 12-36 bulan. Selanjutnya setelah dipilih sampel untuk kelompok kasus dan kontrol berdasarkan z-score tinggi badan menurut umur (TB/U), dilakukan pengumpulan data identitas subjek, berat badan lahir, panjang badan lahir, usia kehamilan, lama ASI eksklusif, usia pengenalan MP-ASI dan pemberian MP-ASI usia 6-12 bulan untuk masing-masing sampel.

Analisis univariat dilakukan untuk mendeskripsikan setiap variabel penelitian. Data yang berdistribusi normal menggunakan rerata, sedangkan untuk data berdistribusi tidak normal maka menggunakan median. ${ }^{18}$ Analisis bivariat dilakukan untuk melihat hubungan variabel dan besar risiko (OR) antara berat badan lahir, panjang badan lahir, usia kehamilan, lama ASI eksklusif, usia pengenalan MP-ASI dan pemberian MP-ASI usia 6-12 bulan dengan kejadian stunting pada anak usia 12-36 bulan. Analisis bivariat menggunakan uji Pearson Chi-Square untuk variabel panjang badan lahir, lama pemberian ASI eksklusif, usia makan pertama dan skor T MP-ASI sedangkan berat badan lahir dan usia kehamilan menggunakan uji Fisher Exact karena syarat uji chi-square tidak terpenuhi. ${ }^{18}$

\section{HASIL PENELITIAN}

Jumlah sampel dalam penelitian ini sebanyak 58 anak balita yang terdiri dari 29 anak stunting dan 29 anak normal. Sebanyak 51,7\% sampel berjenis kelamin perempuan, dan 48,3\% sampel berjenis kelamin laki-laki. Rerata tinggi badan kelompok normal adalah $83,5 \mathrm{~cm}$ sedangkan pada kelompok stunting adalah $77,4 \mathrm{~cm}$. Adapun diskripsi pekerjaan ayah dan pendidikan ibu ditampilkan melalui Tabel 1.

Tabel 1. Diskripsi pekerjaan ayah dan pendidikan ibu pada anak stunting dan normal

\begin{tabular}{llllll}
\hline Gambaran Umum & & \multicolumn{2}{c}{ Anak stunting } & \multicolumn{2}{l}{ Anak normal } \\
\cline { 3 - 6 } & & $\mathrm{n}$ & $\%$ & $\mathrm{n}$ & $\%$ \\
\hline Pekerjaan Ayah & Tidak bekerja & 2 & 6,9 & 0 & 0 \\
& Karyawan pabrik & 13 & 44,83 & 11 & 37,93 \\
& Kuli,petani & 3 & 10,34 & 5 & 17,24 \\
& Wiraswasta & 11 & 37,93 & 12 & 41,38 \\
& Pegawai negeri & 0 & 0 & 1 & 3,45 \\
\hline Pendidikan Ibu & Tamat SD & 4 & 13,79 & 5 & 17,24 \\
& Tamat SMP & 5 & 17,24 & 6 & 20,7 \\
& Tamat SMA & 18 & 62,07 & 13 & 44,82 \\
& Tamat akademi/PT & 2 & 6,9 & 5 & 17,24 \\
\hline
\end{tabular}

Berdasarkan Tabel 2, median lama pemberian ASI eksklusif pada kedua kelompok kurang dari 6 bulan. Bahkan pada kelompok stunting ditemukan praktek pemberian ASI eksklusif hingga usia 12 bulan. Hal ini menunjukkan bahwa terdapat praktek pemberian ASI non-eksklusif pada kelompok stunting maupun normal. Selain itu, pada penelitian ini ditemukan bahwa median usia makan pertama pada kelompok stunting tidak sesuai dengan rekomendasi ADA dan AAP yaitu pemberian makanan pendamping ASI sebaiknya saat usia 6 bulan.

Tabel 2. Diskripsi BB lahir, PB lahir, lama pemberian ASI eksklusif, usia makan pertama dan skor MPASI pada anak stunting dan normal

\begin{tabular}{|c|c|c|c|c|c|}
\hline \multirow[t]{2}{*}{ Karakteristik } & \multicolumn{2}{|c|}{ Anak stunting (pendek) } & \multicolumn{3}{|c|}{ Anak normal } \\
\hline & Median \pm SD & Maks & Median \pm SD & Min & Maks \\
\hline
\end{tabular}




\begin{tabular}{lcccccc}
\hline $\begin{array}{l}\text { Berat badan lahir } \\
(\mathrm{g})\end{array}$ & $2900 \pm 354,1$ & 2000 & 3500 & $3100 \pm 473,4$ & 2500 & 4500 \\
\hline $\begin{array}{l}\text { Panjang badan lahir } \\
(\mathrm{cm})\end{array}$ & $48 \pm 1,6$ & 43 & 50 & $49 \pm 1,4$ & 48 & 52 \\
\hline $\begin{array}{l}\text { Usia kehamilan } \\
\text { (minggu) }\end{array}$ & $37 \pm 1,2$ & 32 & 39 & $37 \pm 0,7$ & 36 & 40 \\
\hline $\begin{array}{l}\text { Lama pemberian } \\
\text { ASI eksklusif (bln) }\end{array}$ & $0,00 \pm 3,7$ & 0 & 12 & $2,0 \pm 2,5$ & 0 & 6 \\
\hline $\begin{array}{l}\text { Usia makan } \\
\text { pertama (bln) }\end{array}$ & $5 \pm 2,6$ & 0 & 12 & $6 \pm 1,9$ & 0 & 8 \\
\hline Skor MP-ASI & $184 \pm 37,14$ & 114 & 254 & $184 \pm 32,08$ & 125 & 264 \\
\hline
\end{tabular}

Sebagian besar sampel pada kelompok stunting maupun normal diberikan bubur instan dan susu formula sebagai makanan/minuman pertama. Pada penelitian ini ditemukan praktek pemberian makanan dan minuman pertama yang kurang tepat pada kelompok stunting maupun normal. Pemberian nasi tim dan susu sapi tidak dianjurkan untuk dikonsumsi bayi sebagai makanan pertama. $^{9} \quad$ Adapun deskripsi jenis makanan dan minuman yang pertama dikonsumsi ditampilkan melalui Tabel 3

Tabel 3. Deskripsi jenis makanan dan minuman yang pertama dikonsumsi oleh anak stunting dan normal

\begin{tabular}{llcccc}
\hline \multicolumn{2}{c}{$\begin{array}{c}\text { Jenis Makanan dan Minuman } \\
\text { yang Pertama Dikonsumsi }\end{array}$} & \multicolumn{2}{c}{$\begin{array}{c}\text { Anak stunting } \\
\text { (pendek) }\end{array}$} & \multicolumn{2}{c}{ Anak normal } \\
\cline { 3 - 6 } & & $\mathrm{N}$ & $\%$ & $\mathrm{n}$ & $\%$ \\
\hline Jenis & Bubur instan & 25 & 86,2 & 24 & 82,8 \\
makana & Bubur beras & 2 & 6,9 & 1 & 3,4 \\
$\mathrm{n}$ & Pisang & - & - & 1 & 3,4 \\
pertama & Bubur instan + pisang & 2 & 6,9 & 2 & 6,9 \\
& Nasi tim & - & - & 1 & 3,4 \\
\hline Jenis & Air putih & 5 & 17,3 & 5 & 17,2 \\
minuma & Susu formula & 23 & 79,3 & 24 & 82,8 \\
n & Susu sapi & 1 & 3,4 & - & - \\
pertama & & & & & \\
\hline
\end{tabular}

Berdasarkan analisis menggunakan uji chisquare atau uji modifikasi fisher, prematuritas dan panjang badan lahir rendah (pendek) merupakan faktor risiko kejadian stunting pada anak usia 1236 bulan. Berat badan lahir, lama pemberian ASI eksklusif, usia makan pertama dan skor MP-ASI bukan merupakan faktor risiko kejadian stunting. Adapun tabel silang faktor risiko kejadian stunting ditampilkan melalui Tabel 4.

Tabel 4. Tabel silang faktor BB lahir, PB lahir, lama pemberian ASI eksklusif, usia makan pertama dan skor MP-ASI dengan kejadian stunting

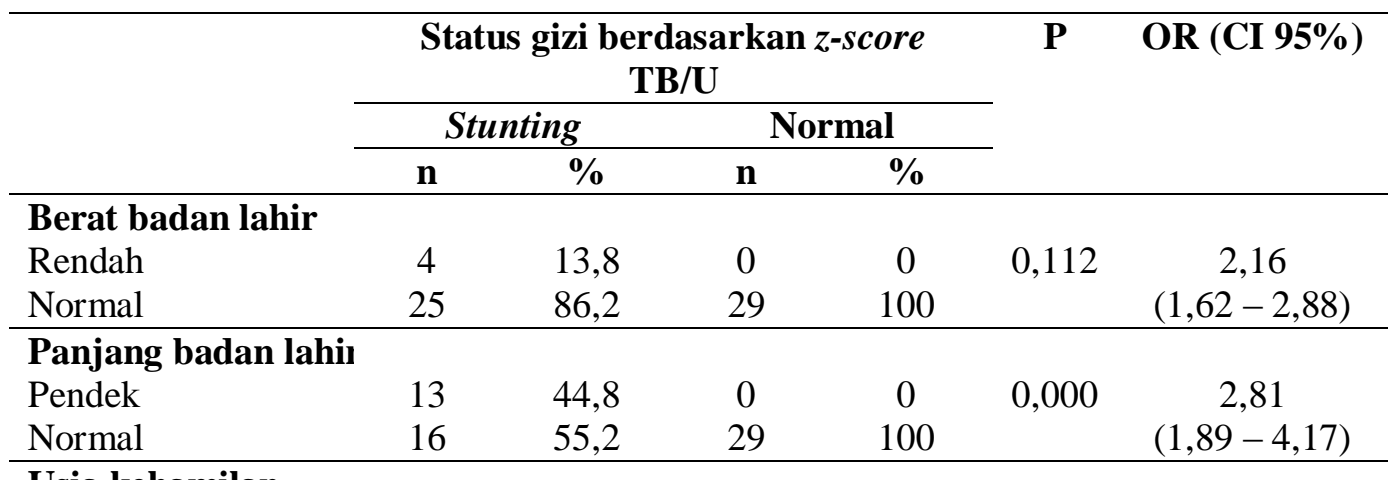

Usia kehamilan 


\begin{tabular}{lcccccc}
$\begin{array}{l}\text { Prematur } \\
\text { Normal }\end{array}$ & 8 & 27,6 & 1 & 3,5 & 0,025 & $\begin{array}{c}10,67 \\
(1,24- \\
91,98)\end{array}$ \\
\hline $\begin{array}{l}\text { Lama pemberian ASI } \\
\text { eksklusif } \\
=6 \text { bln }\end{array}$ & 21 & 72,4 & 28 & 96,5 & & \\
$<$ atau > 6 bln & 25 & 86,2 & 21 & 72,4 & 0,195 & 2,38 \\
\hline $\begin{array}{l}\text { Usia makan pertami } \\
<6 \text { bln }\end{array}$ & 4 & 13,8 & 8 & 27,6 & & $(0,63-9,03)$ \\
$\geq 6$ bln & 16 & 55,2 & 10 & 34,5 & 0,113 & 2,34 \\
\hline $\begin{array}{l}\text { Skor MP-ASI } \\
\text { Kurang }\end{array}$ & 13 & 44,8 & 19 & 65,5 & & $(0,81-6,74)$ \\
Baik & 16 & 55,2 & 16 & 55,2 & 1,000 & 1,15 \\
\hline
\end{tabular}

\section{PEMBAHASAN PENELITIAN}

Berdasarkan sebuah penelitian di Makassar, status gizi bayi dipengaruhi oleh berat badan lahir sebesar 5\% untuk indeks BB/U, 1,4\% untuk indeks $\mathrm{PB} / \mathrm{U}$ dan $0,7 \%$ untuk indeks BB/PB. ${ }^{19}$ Hasil penelitian ini menunjukkan bahwa berat badan lahir bukan merupakan faktor risiko kejadian stunting. Penelitian ini tidak sesuai dengan penelitian di Semarang yang menyatakan bahwa berat badan lahir merupakan faktor risiko kejadian stunting dengan nilai $\mathrm{OR}=11,88(\mathrm{CI}$ $95 \% 1,5-96,1) .{ }^{20}$ Hal ini disebabkan pada penelitian di Semarang, jumlah anak dengan riwayat berat badan lahir rendah (BBLR) pada kelompok kasus lebih banyak, selain itu riwayat BBLR juga ditemukan pada kelompok normal. Pada penelitian ini ditemukan riwayat berat badan lahir rendah hanya dialami oleh kelompok stunting yaitu sebanyak 4 anak tetapi tidak ditemukan pada kelompok normal. Bayi dengan berat badan lahir rendah mengalami retardasi pertumbuhan dalam uterus, baik akut maupun kronis. ${ }^{21}$ Jika bayi tersebut mengalami kurang gizi sejak awal kehamilan maka akan berdampak pada berat maupun panjang badan lahirnya yaitu kurus dan pendek. ${ }^{5}$

Pada penelitian ini juga ditemukan sebanyak $86,2 \%$ anak dengan riwayat berat badan lahir normal yang mengalami stunting. Hal ini dapat disebabkan oleh ketidakcukupan asupan zat gizi pada balita normal yang menyebabkan terjadinya growth faltering (gagal tumbuh). Asupan zat gizi yang rendah serta paparan terhadap infeksi memberikan dampak growth faltering yang lebih berat pada balita normal. ${ }^{5}$

Hasil penelitian ini menunjukkan bahwa panjang badan lahir dan usia kehamilan merupakan faktor risiko kejadian stunting. Hasil tersebut sesuai dengan penelitian di Brazil yang menyatakan bahwa risiko kejadian stunting meningkat pada kelompok bayi prematur usia 12 bulan dengan OR: 2,35 (95\% CI: $1,49-3,7)$ dan pada usia 24 bulan dengan OR: 2,30 (95\% CI: 1,40-3,77). ${ }^{8}$ Penelitian lain di Indramayu menyatakan bahwa rata-rata panjang badan bayi prematur berada di bawah persentil-10. Pertumbuhan yang lambat pada bayi prematur dipengaruhi oleh retardasi linier yang terjadi sejak dalam kandungan selain karena singkatnya usia kehamilan. ${ }^{5}$ Bayi tersebut memiliki ukuran panjang, berat dan lingkar kepala yang kurang dari ukuran normal. ${ }^{7,22}$ Bayi yang mengalami growth faltering sejak usia dini menunjukkan risiko untuk mengalami growth faltering pada periode umur berikutnya. $^{5}$

Stunting yang disebabkan oleh growth faltering dan catch up growth yang tidak memadai, mencerminkan ketidakmampuan untuk mencapai pertumbuhan optimal. ${ }^{5}$ Akan tetapi, jika diberikan dukungan asupan gizi yang adekuat maka pola pertumbuhan normal dapat terkejar (catch up). ${ }^{23}$ Asupan gizi yang adekuat berkaitan dengan kualitas dan kuantitas makanan yang diberikan. Hal ini dipengaruhi oleh status ekonomi. ${ }^{9}$ Status ekonomi yang rendah berdampak pada ketidakmampuan untuk mendapatkan pangan yang cukup dan berkualitas karena rendahnya kemampuan daya beli. ${ }^{24}$ Pada penelitian ini ditemukan sebanyak $62 \%$ ayah sampel pada kelompok stunting memiliki pekerjaan dengan gaji rendah seperti karyawan pabrik, kuli, petani, bahkan ditemukan juga ayah yang tidak bekerja. Status ekonomi sampel juga dapat tercermin dari rumah tinggalnya. Berdasarkan pengamatan, lebih dari separuh sampel kelompok stunting tinggal di rumah dengan kondisi yang minim, seperti lantai dari tanah dan dinding dari kayu/bambu/bata yang belum diplester. Kondisi ekonomi seperti ini 
membuat balita stunting sulit mendapatkan asupan zat gizi yang adekuat sehingga mereka tidak dapat mengejar ketertinggalan pertumbuhan (catch up) dengan baik.

Status ekonomi yang rendah pada kelompok stunting juga berdampak pada higene dan sanitasi yang rendah. Anak yang tinggal di lingkungan dengan sanitasi rendah lebih rawan terkontaminasi bakteri. ${ }^{25}$ Penelitian di Bangladesh melaporkan bahwa komponen Proteobacteria seperti Klebsiella, Escherichia dan Neisseria yang merupakan bakteri patogen, berjumlah lebih banyak pada anak yang malnutrisi. ${ }^{26}$ Penelitian lain di India melaporkan bahwa spesies Campylobacter dan Helicobacter ditemukan berjumlah lebih banyak pada anak malnutrisi. Campylobacter jejuni dan Campylobacter coli merupakan penyebab diare sedangkan Helicobacter menyebabkan inflamasi kronis pada lambung bagian bawah dan berkaitan dengan ulserasi usus dan lambung serta kanker lambung. ${ }^{27}$ Spesies patogen yang ditemukan dalam jumlah banyak pada anak malnutrisi menunjukkan bahwa anak tersebut sering menderita infeksi saluran cerna sehingga berakibat pada malabsorbsi zat gizi dan penurunan kesehatan. ${ }^{26}$ Growth faltering dapat terjadi ketika asupan makanan dan absorbsi zat gizi oleh vili berkurang tetapi kebutuhan zat gizi untuk pertumbuhan meningkat. ${ }^{25}$

Rekomendasi dari The American Dietetic Association (ADA) dan The American Academy of Pediatric (AAP) adalah agar ASI diberikan eksklusif kepada bayi selama 6 bulan pertama kemudian dilanjutkan dengan diberikan makanan pendamping ASI (MP-ASI) minimal hingga usia 12 bulan. ${ }^{28}$ Berdasarkan hasil penelitian di Banten, bayi stunting yang tidak diberikan ASI eksklusif selama 6 bulan mempunyai risiko 3,7 kali tetap stunting pada usia 3 - 4 tahun. Pengaruh ASI eksklusif terhadap perubahan status stunting disebabkan oleh fungsi ASI sebagai antiinfeksi. Pemberian ASI yang kurang dan pemberian makanan atau formula terlalu dini dapat meningkatkan risiko stunting karena bayi cenderung lebih mudah terkena penyakit infeksi seperti diare dan penyakit pernafasan. ${ }^{11,20}$ Pada penelitian ini ditemukan lebih banyak balita normal yang menerima ASI eksklusif $(27,6 \%)$ daripada balita stunting (13,8\%). Akan tetapi, hasil penelitian ini tidak sesuai dengan hasil penelitian di Banten. Penelitian ini menunjukkan bahwa ASI eksklusif bukan merupakan faktor risiko kejadian stunting pada balita usia 12-36 bulan. Berdasarkan wawancara dengan ibu balita sampel, sebagian besar ibu balita mengkombinasikan pemberian ASI dengan susu formula. Berbagai alasan dikemukakan oleh ibu balita seperti ASI belum/susah keluar, ibu tidak dapat memberikan ASI saja karena bekerja, sudah diberikan susu formula oleh rumah bersalin sejak lahir dan bayi masih rewel meskipun sudah diberi ASI. Pemberian ASI bersamaan dengan susu formula dapat memenuhi kebutuhan zat gizi bayi sehingga pertumbuhannya tidak terganggu. Akan tetapi, susu formula tidak mengandung zat antibodi sebaik kandungan zat antibodi pada ASI sehingga bayi lebih rawan terkena penyakit.

Pada penelitian ini ditemukan sebanyak 2 balita stunting yang menerima ASI eksklusif hingga usia 12 bulan, tetapi hal tersebut tidak ditemukan pada balita normal. Pemberian ASI eksklusif terlalu lama (> 6 bulan) dapat menyebabkan bayi kehilangan kesempatan untuk melatih kemampuan menerima makanan lain sehingga susah menerima bentuk makanan selain cair. Hal tersebut dapat menyebabkan growth faltering karena bayi mengalami defisisensi zat gizi. Sebuah penelitian di Senegal menyatakan bahwa ASI eksklusif yang diberikan selama lebih dari 2 tahun berhubungan dengan rata-rata $z$-score TB/U yang rendah. Pada penelitian tersebut, ditemukan prevalensi stunting yang lebih tinggi pada balita yang diberikan ASI eksklusif selama lebih dari 2 tahun. ${ }^{23}$

Sejak usia 6 bulan, pemberian ASI saja tidak dapat mencukupi kebutuhan zat gizi bayi sehingga dibutuhkan tambahan sumber zat gizi dari makanan pendamping ASI. ${ }^{16}$ Waktu pemberian MP-ASI yang tepat tergantung pada kebutuhan dan kesiapan mental masing-masing bayi karena perbedaan kecepatan pertumbuhan, aktivitas dan kondisi lingkungan. ${ }^{22}$ MP-ASI dapat mulai diberikan saat usia 6 bulan karena perkembangan bayi sudah mendukung untuk mulai diberikan MPASI. $^{7}$ Sebuah penelitian di India melaporkan bahwa pemberian MP-ASI pada usia dini $(0-2$ bulan) dapat meningkatkan risiko stunting pada balita usia $24-48$ bulan. ${ }^{12}$ Pada penelitian ini, median usia pemberian makan pertama pada kelompok stunting maupun normal lebih dari usia 2 bulan yaitu usia 5 bulan pada kelompok stunting dan 6 bulan pada kelompok normal sehingga hasil penelitian ini menunjukkan bahwa usia makan bukan merupakan faktor risiko kejadian stunting.

Gangguan pertumbuhan linier dapat terjadi saat kualitas dan kuantitas MP-ASI yang diberikan rendah. ${ }^{4}$ Ibu berperan penting dalam menentukan kualitas dan kuantitas MP-ASI. Tinggi rendahnya 
pendidikan ibu berkaitan erat dengan pengetahuan terhadap gizi. ${ }^{10}$ Berdasarkan hasil penelitian di Bogor, lama pendidikan ibu berhubungan dengan status gizi balita menurut skor $\mathrm{z}$ indeks $\mathrm{TB} / \mathrm{U} .^{9}$ Hal tersebut sesuai dengan penelitian ini yaitu ditemukan sebanyak $17,24 \%$ ibu sampel dari kelompok normal memiliki pendidikan setingkat akademi/perguruan tinggi sedangkan pada kelompok stunting hanya $6,9 \% .^{9}$

Pemberian MP-ASI pada balita dinilai menggunakan kuesioner yang terdiri dari beberapa pertanyaan mengenai frekuensi, jenis MP-ASI serta komposisi hidangan makan yang diberikan saat usia $6-12$ bulan. Berdasarkan hasil penelitian, skor MP-ASI bukan merupakan faktor risiko kejadian stunting pada balita usia $12-36$ bulan. Sebanyak 55,2\% sampel dari kelompok stunting maupun normal mempunyai skor MP-ASI yang kurang. Hal ini dapat disebabkan oleh beberapa hal seperti balita belum diberikan lauk hewani ataupun nabati, frekuensi pemberian makan yang kurang dan komposisi menu makan yang tidak tepat.

Pada usia 6 - 8 bulan sebaiknya bayi diberikan makanan lunak terlebih dahulu seperti sereal fortifikasi besi, puree sayuran dan biskuit bayi. ${ }^{7,28}$ Berdasarkan wawancara dengan ibu balita sampel, sebanyak $86,2 \%$ sampel dari kelompok stunting dan $82,8 \%$ sampel dari kelompok normal diberikan bubur instan sebagai makanan pertama karena proses pembuatannya yang praktis, mudah didapatkan dan bergizi. Produksi bubur instan sebagai MP-ASI komersial telah diatur dalam keputusan menteri kesehatan RI nomor 224/Menkes/SK/II/2007 tentang spesifikasi teknis MP-ASI. MP-ASI komersial harus mengandung 400 - $440 \mathrm{kkal}$ energi, 15 - $22 \mathrm{~g}$ protein, $10-15 \mathrm{~g}$ lemak serta berbagai vitamin dan mineral lainnya. ${ }^{29}$ Sebanyak $40 \%$ MP-ASI yang diolah di rumah mempunyai kandungan energi, lemak, besi dan vitamin $\mathrm{D}$ yang lebih rendah tetapi tinggi natrium sehingga MP-ASI komersial lebih seimbang zat gizinya daripada MP-ASI olahan rumah. ${ }^{7}$ Pada penelitian ini juga ditemukan praktek pemberian makanan dan minuman pertama yang tidak tepat yaitu pemberian nasi tim dan susu sapi. Nasi tim tidak dianjurkan karena perkembangan kemampuan mengunyah belum sempurna sehingga nasi tim sulit dikonsumsi dalam jumlah yang cukup untuk memenuhi kebutuhan energi. ${ }^{7,28}$ Selain itu, pemberian susu sapi pada tahun pertama tidak dianjurkan oleh AAP (The American Academy of Pediatric). Bayi yang diberikan susu sapi mempunyai asupan besi, asam linoleat, vitamin $\mathrm{C}$ dan vitamin $\mathrm{E}$ yang rendah tetapi asupan natrium, kalium, kalsium dan proteinnya berlebih. Kandungan kalsium yang tinggi dan vitamin $\mathrm{C}$ yang rendah dapat mengahambat absorbsi zat besi. Selain itu, kandungan protein yang tinggi juga dapat memperberat kerja ginjal bayi. Pada bayi dengan usia kurang dari 6 bulan, susu sapi dapat menyebabkan perdarahan pada saluran cerna. ${ }^{7,28}$

\section{SIMPULAN}

Faktor risiko kejadian stunting pada anak usia 1236 bulan di kecamatan Pati, kabupaten Pati adalah prematuritas dan panjang badan lahir rendah (pendek).

\section{KETERBATASAN PENELITIAN}

Pada penelitian ini terdapat keterbatasan dalam pengukuran pola pemberian MP-ASI karena kuesioner pola pemberian MP-ASI tidak dapat menghitung besar asupan zat gizi dari MP-ASI.

\section{SARAN}

1. Pemberian suplementasi/makanan tambahan kepada wanita usia subur yang mengalami KEK oleh dinas kesehatan sebaiknya dilakukan untuk pencegahan terjadinya kurang gizi sebelum kehamilan agar nantinya tidak terjadi gangguan pertumbuhan janin (intrauterine growth retardation) saat kehamilan.

2. Pengawasan kandungan gizi bubur instan oleh badan POM dan dinas kesehatan saat pengurusan ijin sebelum dipasarkan di masyarakat.

3. Pada penelitian selanjutnya, disarankan untuk mengadakan penelitian mengenai penyebab kelahiran prematur dan panjang badan pendek agar kejadian stunting dapat dicegah sejak dini.

\section{DAFTAR PUSTAKA}

1. Badan Penelitian Dan Pengembangan Kesehatan Kementerian Kesehatan RI. Riset kesehatan dasar 2010: Laporan Nasional [serial online]. 2010 [dikutip 26 februari 2012]. Diunduh dari: http://www.riskesdas.litbang.depkes.go.id

2. World Health Organization. Nutrition landscape information system (NLIS) country profile indicators: interpretation guide [serial online]. 2010 [dikutip 10 Mei 2012]. Diunduh dari: http://www.who.int/nutrition

3. Sari M, Pee Sd, Bloem MW, Sun K, ThorneLyman AL, MoenchPfanner R, et al. Higher household expenditure on animal-source and nongrain foods lowers the risk of stunting among children 0-59 
months old in Indonesia: implications of rising food prices. The Journal of Nutrition. 2010; 140:196-200.

4. Caulfield LE, Richard SA, Rivera JA, Musgrove P, Black RE. Stunting, wasting and micronutrient deficiency disorders. In: Jamison DT, Breman JG, Measham AR, Alleyne G, Cleason M, Evans DB, et al, editors. Disease control priorities in developing countries. 2nd ed. New York: The World Bank and Oxford University Press; 2006. p. 551-67

5. Kusharisupeni. Peran status kelahiran terhadap stunting pada bayi: sebuah studi prospektif. Jurnal Kedokteran Trisakti. 2002; 23: 73-80.

6. Kusharisupeni. Growth faltering pada bayi di kabupaten indramayu jawa barat. Makara Kesehatan. 2002; 6: 1-5

7. Whitney E, Rolfes SR. Understanding nutrition. 11 th ed. USA: Thomson Wadsworth; 2008. p. 5257, 550-6,

8. Santos IS, Matijasevich A, Dominingues MR, Barros AJ, Victoria CG, Barros FC. Late preterm birth is a risk factor for growth faltering in early childhood: a cohort study. BMC Pediatr. 2009;9: 71-8.

9. Masithah T, Soekiman, Martianto D. Hubungan pola asuh makan dan kesehatan dengan status gizi anak batita di Desa Mulya Harja. Media Gizi dan Keluarga. 2005; 29: 29-39.

10. Faiza R, Elnovriza D, Syafianti. Faktor risiko kejadian gizi buruk pada anak (12-59 bulan) di wilayah kerja Puskesmas Andalas Kecamatan Padang Timur Kota Padang tahun 2007. Media Gizi dan Keluarga. 2007; 31: 80-6.

11. Rahayu LS. Associated of height of parents with changes of stunting status from 6-12 months to 3-4 years [Tesis]. Yogyakarta: Universitas Gajah Mada; 2011.

12. Padmadas SS, Hutter I, Willekens F. Weaning initiation patterns and subsequent linier growth progression among children aged 2-4 years in India. International Journal of Epidemiology 2002; 31: 855-63.

13. Badan Penelitian dan Pengembangan Kesehatan Departemen Kesehatan RI. Riset Kesehatan Dasar 2007: Laporan Provinsi Jawa Tengah [serial online]. 2008 [dikutip 26 februari 2012]. Diunduh dari: http://www.dinkesjatengprov.go.id

14. Kementerian kesehatan RI. Panduan pelayanan kesehatan bayi baru lahir berbasis perlindungan anak. 2010. hlm 19, 27.

15. American academy of pediatrics. Committe on nutrition: breastfeeding and the use of human milk. Pediatrics. 2005; 115: 496.

16. Poskitt EME, Morgan JB. Infancy, childhood and adolescene.In: Geissler CA, editor. Human Nutrition. 11th ed. China: Elsevier Churchill Livingstone. 2005. p. 289-91.
17. Azwar S. Sikap manusia teori dan pengukurannya. Yogyakarta: Pustaka pelajar; 2008. hlm 156.

18. M. Sopiyudin Dahlan. Statistik untuk kedokteran kesehatan. Ed 4. Jakarta: Salemba Medika. 2009. hlm 21, 141-144.

19. Fatimah S. Dampak berat badan lahir terhadap status gizi bayi. Badan Litbang kesehatan [serial online]. 2009 [dikutip 2 Maret 2012]. Diunduh dari: http://diglib.litbang.depkes.go.id

20. Candra A, Puruhita N, Susanto JC. Risk factor of stunting among $1-2$ years old children in Semarang city. Media medika Indonesiana. 2011; 45: 206-12.

21. Akram DS, Arif F. Ponderal index of low birth weight babies-a hospital based study. JPMA. 2005; 55: 229.

22. Morrice JS, Suliva PB. Failure to thrive/ malnutrition. In: Guandalini S, editor. Essential pediatric gastroenterology. USA: The MacGrawHill Companies; 2005. p. 52.

23. Simondon KB, Costes R, Delaunay V, Diallo A, Simondon F. Children's height, health and appetite influence mothers weaning decisions in rural Senegal. International journal of epidemiology. 2001; 30: 476-48.

24. Ulfani DH, Martianto D, Baliwati YF. Faktorfaktor sosial ekonomi dan kesehatan masyarakat kaitannya dengan masalah gizi underweight, stunnting dan wasted di Indonesia: pendekatan ekologi gizi. Jurnal gizi dan pangan. 2011; 6: 5965.

25. Humphrey JH. Child undernutrition, tropical enteropathy, toilets and handwashing. Lancet. 2009; 374: 1032-35.

26. Monira S, Nakamura S, Gotoh K, Izutsu K, Watanabe H, Alam NH, et al. Gut microbiota of healthy and malnourished children in Bangladesh. Frontiers in microbiology. 2011; 2: 1-7.

27. Gupta SS, Mohammed MH, Ghosh TS, Kanugo S, Nair GB, Mande SS. Metagenome of the gut of a malnourished children. Gut pathogens. 2011; 3: 19.

28. Trahms CM, McKean KN. Nutrition during infancy. In: Mahan LK, EscottStump S, editors. Krause`s food, nutrition, and diet therapy. $11^{\text {th }}$ ed. USA : Saunders. 2004. p. 206-8, 215, 224, 232, 384.

29. Kementerian kesehatan RI. Keputusan menteri kesehatan RI No. 224/Menkes/SK/II/2007 tentang spesifikasi teknis makanan pendamping ASI (MPASI) bubuk instan untuk bayi $6-12$ bulan [serial online]. 2007 [dikutip 23 Juni 2012]. Diunduh dari: http://gizi.depkes.go.id. 